Research Article

\title{
Combustion Characteristics of Mui and Taru Basin Coal in a Fluidized Bed Combustor
}

\author{
Brian Ondari $\left(\mathbb{D},{ }^{1}\right.$ Zachary Siagi $\left(\mathbb{D},{ }^{1}\right.$ and Anil Kumar $\mathbb{D}^{2}$ \\ ${ }^{1}$ Department of Mechanical, Production and Energy Engineering, School of Engineering, Moi University, Eldoret 30100, Kenya \\ ${ }^{2}$ Department of Chemical and Process Engineering, School of Engineering, Moi University, Eldoret 30100, Kenya \\ Correspondence should be addressed to Brian Ondari; ondaribrian@mu.ac.ke
}

Received 25 December 2020; Revised 2 May 2021; Accepted 13 May 2021; Published 27 May 2021

Academic Editor: Constantine D. Rakopoulos

Copyright (C) 2021 Brian Ondari et al. This is an open access article distributed under the Creative Commons Attribution License, which permits unrestricted use, distribution, and reproduction in any medium, provided the original work is properly cited.

Coal reserves at Mui and Taru in Kitui and Kilifi counties in Kenya are estimated to provide over 400 million tons. Being new discoveries, their properties were investigated using the ASTM standards, while the combustion characteristics were studied in a fluidized bed combustor (FBC). Proximate analyses of the Mui1, Mui2, and Taru coal samples were as follows: moisture content $3.75,5.48$, and 3.53\%; volatile matter 59.25, 58.05, and 55.10\%; ash content 9.25, 11.48 , and 24.63\%; and fixed carbon 27.80, 25.00, and $16.75 \%$, respectively. Ultimate analysis for Mui1, Mui2, and Taru coal samples is as follows: sulphur wt.\% 1.94, 1.89, and 1.07; carbon 65.68, 60.98, and 51.10\%; hydrogen 5.97, 5.70, and 5.09\%; nitrogen 0.92, 0.94, and 1.00\%; and oxygen 11.62, 12.33, and $11.13 \%$, respectively. Temperature-weight loss analysis showed that for Mui and Taru basin coal, devolatilization starts at $200^{\circ} \mathrm{C}$ and $250^{\circ} \mathrm{C}$, and combustion was complete at $750^{\circ} \mathrm{C}$ and $650^{\circ} \mathrm{C}$, respectively. The maximum temperature obtained in $\mathrm{FBC}$ was $855^{\circ} \mathrm{C}$ at $700 \mathrm{~mm}$ height, just above the point of fuel feed, while the minimum was $440^{\circ} \mathrm{C}$ at height of $2230 \mathrm{~mm}$. Maximum pressure drop was $1.02 \mathrm{mbars}$ at $150 \mathrm{~mm}$, while minimum was $0.67 \mathrm{mbars}$ at $700 \mathrm{~mm}$ from the base. Gross calorific values were Muil coal, $27090 \mathrm{~kJ} / \mathrm{kg}$ (grade A), Mui2 coal, $25196 \mathrm{~kJ} / \mathrm{kg}$ (grade B), and the Taru coal, $21016 \mathrm{~kJ} / \mathrm{kg}$ (grade C). Flue gas analysis for Taru and Mui coal gave hydrogen sulfide as $20 \mathrm{ppm}$ and $6 \mathrm{ppm}$, maximum carbon monoxide of $2000 \mathrm{ppm}$ at $600^{\circ} \mathrm{C}$, and a decrease in oxygen as combustion progressed to a minimum of $15 \%$, followed by an increase to $20.3 \%$, suggesting depletion of coal. Based on the findings, the coal samples were suitable for commercial use.

\section{Introduction}

Energy is one of the key sectors towards the development of any given region [1]. With Kenya's vision 2030 [2], the country has to invest more in energy generation to meet future increase in demand. In recent years, the Government of Kenya has been keen to increase the share of renewable energy sources in the country's generation mix [3]. However, with the discovery of fossil fuels in the country including coal deposits at Mui in Kitui and Taru basin in Kilifi County, oil in Turkana County, and natural gas in Wajir, it is shifting towards a mixed approach encompassing development of both renewable energy plants and fossil fuel generators [4]. As at November 2019, Kenya had 2651 MW grid connection of electricity [5]. Geothermal lead with $44 \%$ outdoing hydropower $(33 \%)$ and thermal (11\%) which had influence from droughts and global fuel prices, respectively $[6,7]$. To increase the number of energy sources, coal is being explored by the government, since it is cheaper than hydro and geothermal despite known negative impacts on the environment such as generation of greenhouse gas, carbon dioxide, and air pollution due to sulphur oxides, nitrogen oxides, coal dust, coal combustion wastes, and coal sludge [8].

Coal is combustible black sedimentary rocks that are formed as a result of continuous exposure to high temperature and high pressure of ancient plants such as trees, fern, and mosses which grew in swamps along the shoreline of the coastal region. The transitional stages to the formation of coal are peat, lignite, subbituminous coal, bituminous coal, and anthracite [9]. Anthracite is the most carbon-rich, moisture-deficient form of coal and has the highest heating value [10]. Coal is the most abundant fossil fuel in the world, and it is widely used in industries making a major contribution to the global economy [11]. It is mined for 
commercial purposes in more than 50 countries and used in more than 70 countries. 5800 million tons of coal are consumed annually in the world, out of which about $75 \%$ is used for the production of electricity [12]. According to the International Energy Agency, this demand is expected to grow by around $60 \%$ in the next 30 years especially in developing countries. In Kenya, coal is mainly used by cement manufacturers to complement heavy fuel oil for processing heat [13]. A total of 537359 tons of coal was imported and consumed in Kenya by 2016 ranking it 81st in the world [14]. Kenya discovered commercial quantities of coal in one of four coal exploration blocks in the Mui basin of Kitui County, located over $200 \mathrm{~km}$ northeast of Nairobi, with a reserve estimate of more than 400 million tons $[15,16]$. Another major discovery of coal was at the Taru basin in Kilifi and Kwale counties whose resources are expected to be worth over 27 billion US dollars [17]. The coal, therefore, has a role to play towards a sustainable energy in the coming years. As per the 2013 Least Cost Power Development Plan, coal is projected to provide at least $4,500 \mathrm{MW}$ of electricity by 2030 [13]. Characteristics properties (proximate, ultimate, and temperature-weight loss analysis) and fluidized bed combustion characteristics of Mui and Taru basins were studied to assess the commercial viability of the two coals.

\section{Materials and Methods}

For a fluidized bed combustor (FBC), the silica sand was sieve analyzed, and an average particle size of $325 \mu \mathrm{m}$ was used as bed material, since sand particle size of $300-3 \mathrm{~mm}$ is the best in FBC [18]. For a low pressure drop, bed height was $0.1 \mathrm{~m}$, which is equivalent to $0.00177 \mathrm{~m}^{3}$ of sand [19].

Coal was obtained from Mui (Muil and Mui2) and Taru in Kitui and Kilifi counties.

Other equipment used in this study included a digital gas analyzer (Altair 5x) to analyse oxygen, carbon monoxide, combustibles, and hydrogen sulfide in the flue gas, the artificial neural network (ANN) model [20] to determine the elemental organic components in the coal samples, the PTC furnace (Carbolite Gero) for proximate and temperatureweight loss analysis.

FBC had a combustion chamber of diameter $0.15 \mathrm{~m}$ and height of $2.5 \mathrm{~m}$, fitted with 4 pairs of electrical coil heaters to aid in the combustion. The fuel feed to the combustion chamber is fed in the hopper and flows down to the electric, water cooled, screw feeder. Flue gas passes through course and a fine particle separator before being released to the atmosphere as shown in Figure 1.

2.1. FBC Calibration. FBC was calibrated for feed rate, temperature, and pressure along the column length.

For feed rate calibration, screw was disconnected from the FBC and coal input (g/min) was measured at screw revolution per minute (RPM) of $10,20,30$, and 40 , respectively. The results are shown in Figure 2.

Figure 2 shows a linear relationship which is correlated as

$$
Y=115.94 x+118.8
$$

where $Y$ is the feed rate $(\mathrm{g} / \mathrm{min}$.) and $x$ is the RPM.

During temperature calibration of the FBC, the compressor, fan, and the heaters were switched on with only the bed material in the combustor. The temperatures along the combustor chamber were captured by the sensors: $T_{1}, T_{2}, T_{3}$, and $T_{4}$. The highest temperature was recorded by sensor $T_{4}$ and stabilized at around $700^{\circ} \mathrm{C}$; this was followed by $T_{2}$ at $535^{\circ} \mathrm{C}$, then $T_{3}$ at around $500^{\circ} \mathrm{C}$, and least was with $T_{4}$, stabilizing at $346^{\circ} \mathrm{C}$ as shown in Figure 3 .

For pressure measurements, the pressure sensors $P_{1}, P_{2}$, $P_{3}$, and $P_{4}$ gave the pressures.

At $P_{1}$, the lowest point of the four locations, the pressure was the highest pressure, 1.02 mbars. This was attributed by the fact that incoming air from the compressor was first received here. The value is relatively low because of the capacity for the compressor.

The lowest pressure, $0.67-0.68$ mbars, was recorded at $P_{2}$, which was the point adjacent to feed; at this point, pressure dropped drastically because it was interfered with by the fuel feed. $P_{3}$ and $P_{4}$ had pressures 0.97 mbars and 0.81 mbars, respectively.

Agglomeration behavior involved combusting the coal at constant temperature and pressure and then closely examining the drained materials [21], as shown in Figures 4(a) and 4(b). Temperature variation recorded by sensors $T_{1}, T_{2}$, $T_{3}$, and $T_{4}$ obtained from coal combustion are shown in Figures 5 and 6. Results are shown in Figure 7.

2.2. Proximate, Ultimate, and Temperature-Weight Loss Analysis. Proximate analysis was done in accordance with the ASTM (D-3172) standards with the use of an oven and a digital weighing balance. In analysis of sulphur, a digital bomb calorimeter (Toshniwal) was used, while for temperature-weight loss analysis, $2 \mathrm{~g}$ of coal was combusted in an oven (Carbolite Gero batch) and weight loss expressed as percentage of original weight.

\section{Results and Discussion}

3.1. Proximate Analysis. Proximate analysis results consisting of moisture content (MC), volatile matter (VM), ash content (A), and the fixed carbon content (FC) percentage mass of the coal samples are given in Table 1.

Coal with high $\mathrm{MC}$ has a longer heating time, consuming more energy and formation of volatiles [22]; this negatively affects GCV [23], while high VM leads to ease ignition, increased reactivity, and spontaneous combustion though it requires a larger combustion chamber in $\mathrm{FBC}$ and furnaces $[11,24]$. High ash content causes clinkering, declining reaction rate in combustion and environmental pollution [25]; this is likely to be the case with Taru coal. Mui coal is likely to have a higher heating value than Taru coal due to higher FC $[26,27]$.

3.2. Ultimate Analysis. Elemental analysis results consisting of carbon $(\mathrm{C})$, mineral matter (MM), oxygen $(\mathrm{O})$, hydrogen $(\mathrm{H})$, sulphur $(\mathrm{S})$, and nitrogen $(\mathrm{N})$ are given in Table 2. 


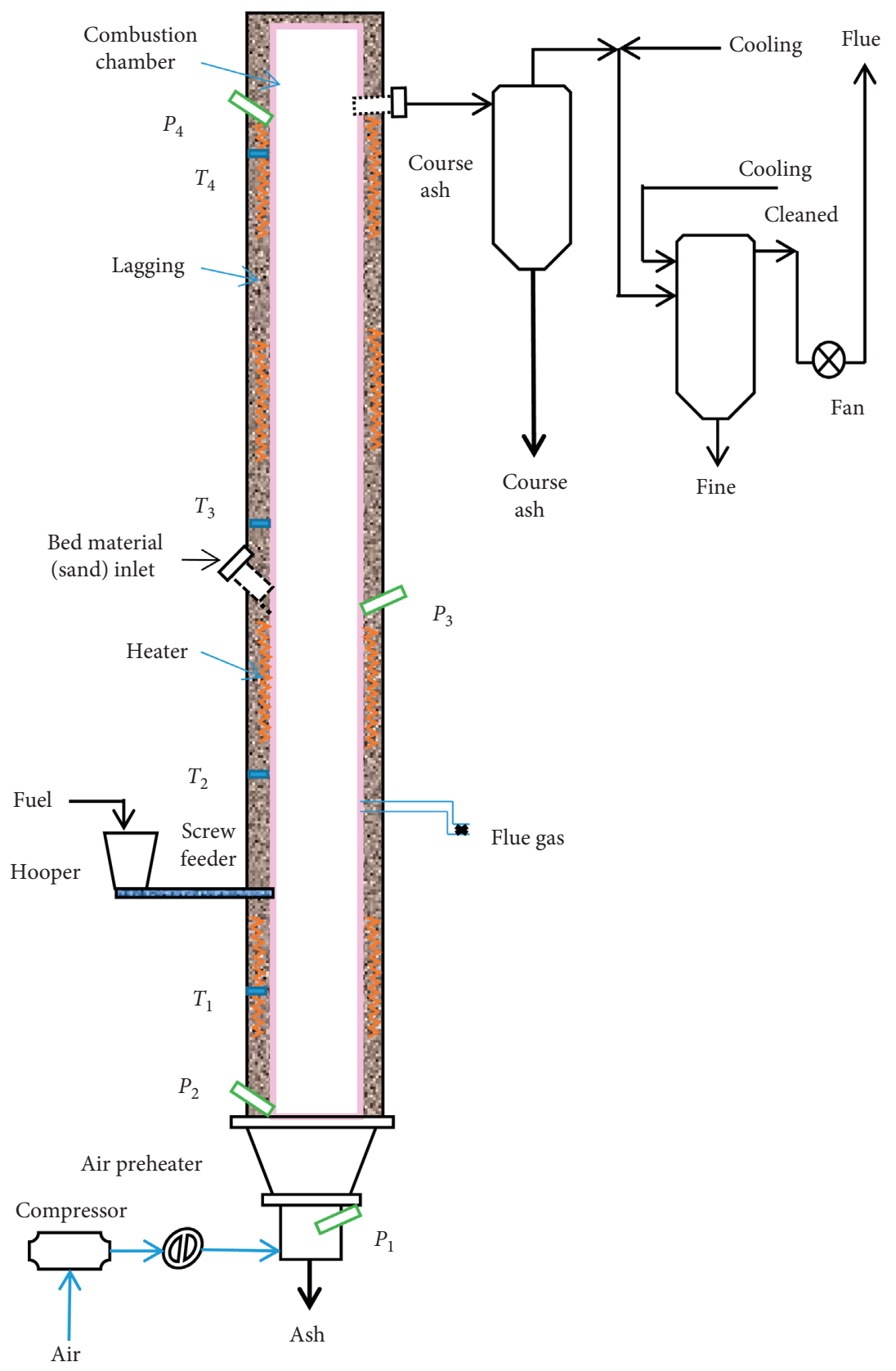

Figure 1: Schematic diagram of FBC.

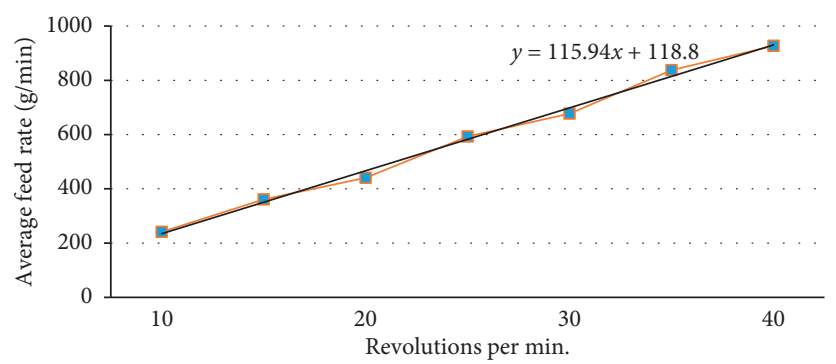

Figure 2: Plot of average feed rate against revolution per minute. 


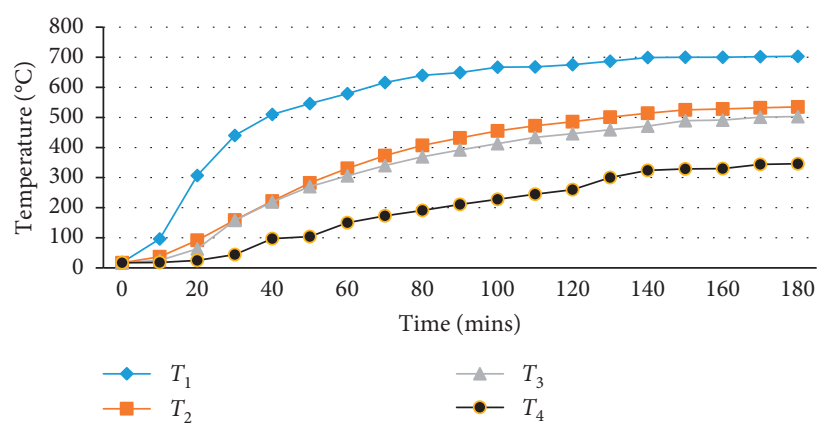

Figure 3: Plot of temperature versus time.

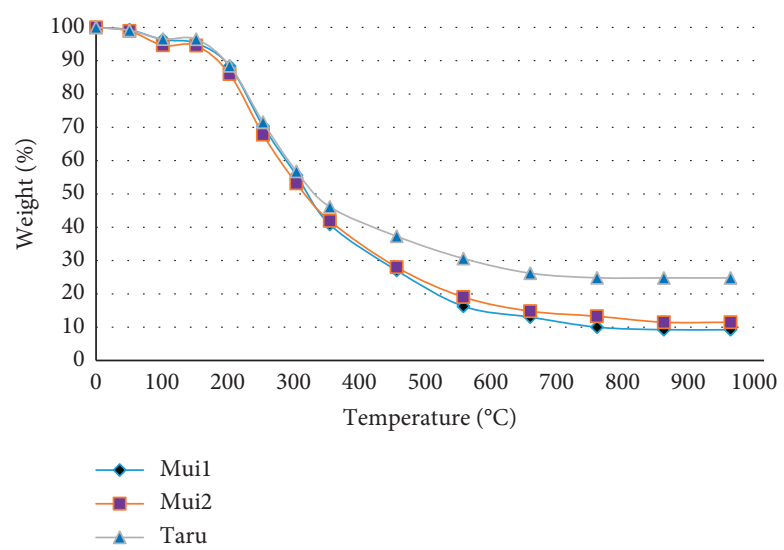

Figure 4: Plot of temperature-weight analysis Mui1, Mui2, and Taru coal.

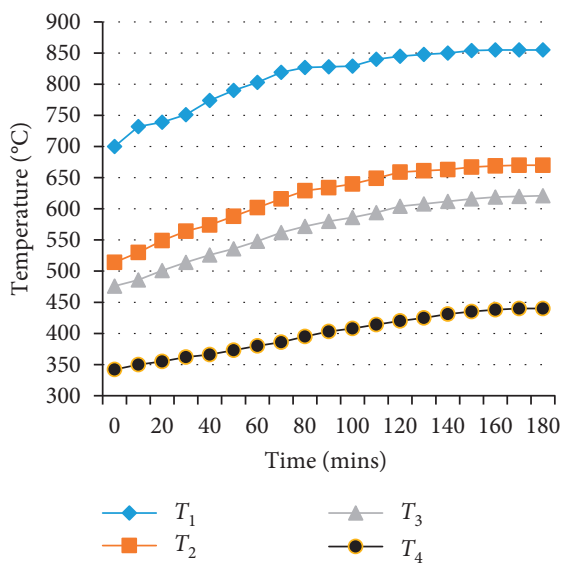

(a)

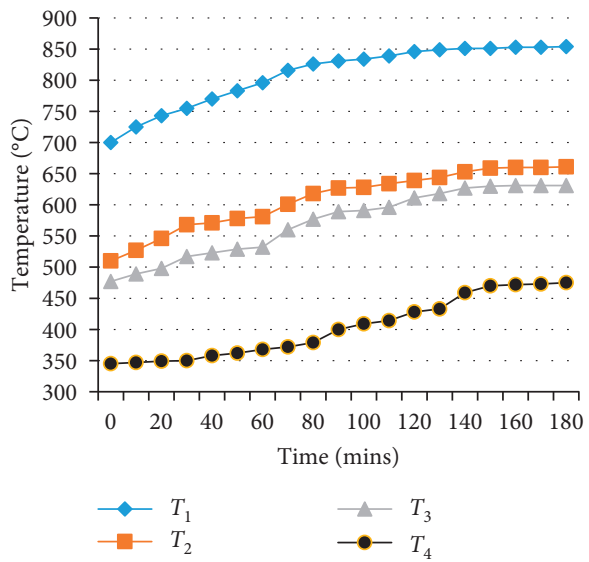

(b)

Figure 5: Plot of temp against time for (a) Mui and (b) Taru coal.

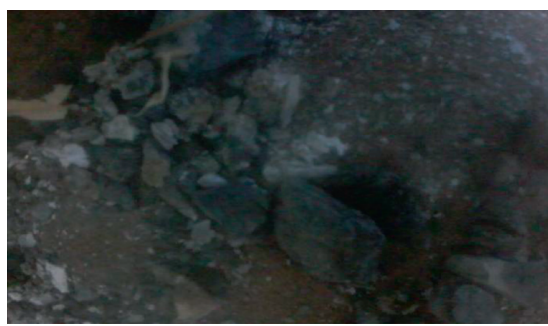

(a)

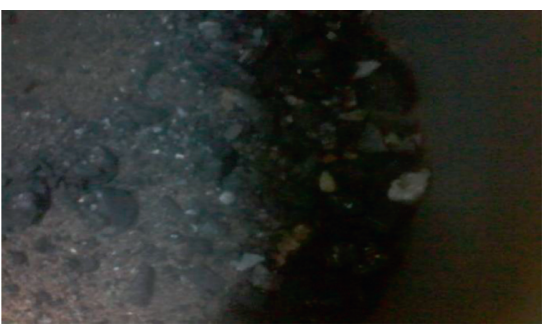

(b)

Figure 6: Drained material from FBC after combustion. (a) Mui and (b) Taru coal. 


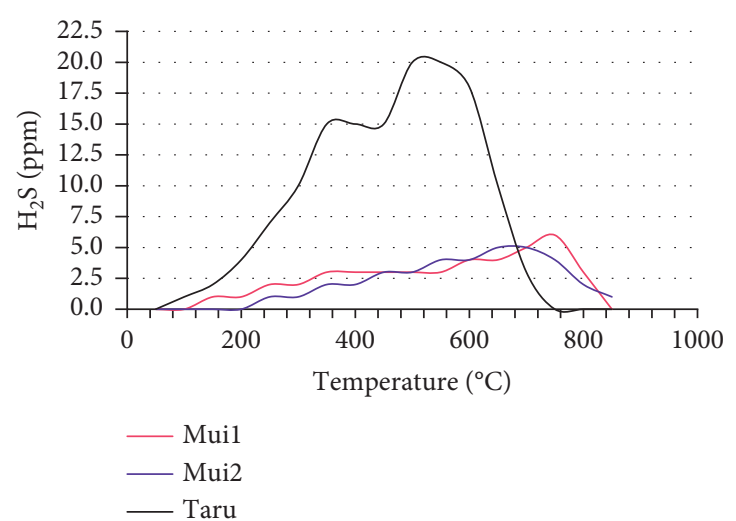

(a)

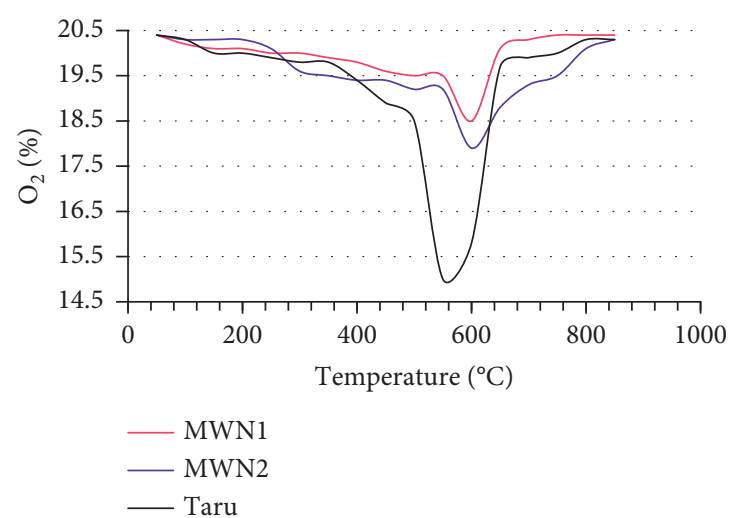

(c)

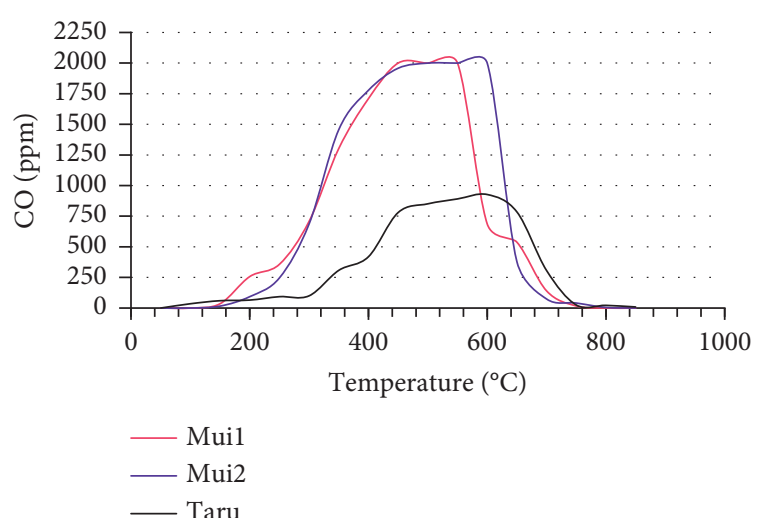

(b)

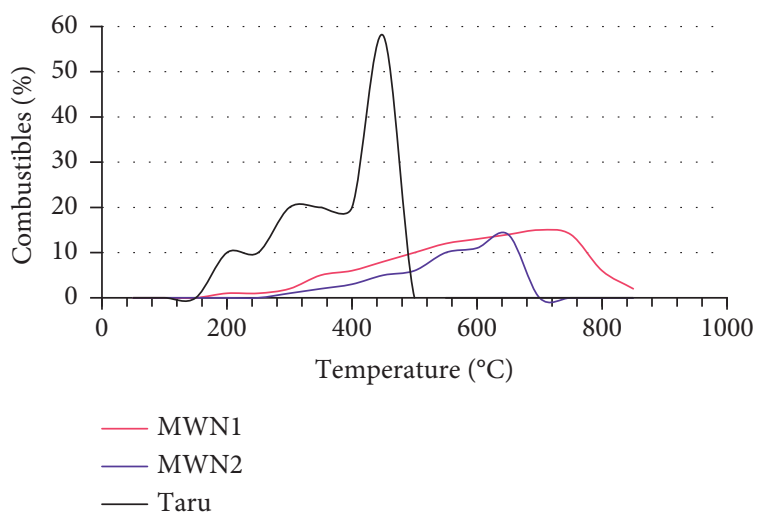

(d)

Figure 7: Plot of (a) $\mathrm{H}_{2} \mathrm{~S}$ in ppm, (b) $\mathrm{CO}$ in ppm, (c) $\mathrm{O}_{2} \%$, and (d) combustibles \% against temperature.

TABle 1: Proximate results.

\begin{tabular}{lcccc}
\hline \multirow{2}{*}{ Coal sample } & \multicolumn{4}{c}{ Mass composition (\%) } \\
& MC & VM & $A$ & FC \\
\hline Muil & 3.75 & 59.25 & 9.25 & 27.80 \\
Mui2 & 5.48 & 58.05 & 11.48 & 25.00 \\
Taru & 3.53 & 55.10 & 24.63 & 16.75 \\
\hline
\end{tabular}

TABLE 2: Ultimate analysis results for Taru and Mui basins coals.

\begin{tabular}{lcccccc}
\hline \multirow{2}{*}{ Coal sample } & \multicolumn{7}{c}{ Mass composition (\%) } \\
& $\mathrm{C}$ & $\mathrm{MM}$ & $\mathrm{O}$ & $\mathrm{H}$ & $\mathrm{S}$ & $\mathrm{N}$ \\
\hline Mui1 & 65.68 & 10.18 & 11.62 & 5.97 & 1.89 & 0.92 \\
Mui2 & 60.98 & 12.63 & 12.33 & 5.70 & 1.94 & 0.94 \\
Taru & 51.10 & 27.09 & 11.13 & 5.09 & 1.07 & 1.00 \\
\hline
\end{tabular}

Heating value of $S$ is about a third the heating value of same quantity of carbon per unit [28]. Mui and Taru coal sulphur is in medium sulphur coal [29] and slightly above that of Waterberg and Indian which is 1.49 and 0.6 (wt.\%), respectively $[22,29]$. Carbon is the chief heat source accounting between $60 \%$ and $80 \%$ in lignite and anthracite. Hydrogen accounts to approximately $5 \%$ of coal elemental composition, and its heating value is slightly above four times the heating value of same quantity of carbon though part of it combines with oxygen to form water reducing hydrogen utilized for heat generation. The oxygen in coal combines with carbon, partially oxidizing it, hence reducing combustibility [28]. Mineral matter represents the inorganic element combined with organic elements of coal. The origin of such material is the plant materials from which the coal was formed [30]. Normally, nitrogen in coal is $0.5-2 \%$, where it is below $1 \%$ for anthracite and $1.5-1.75$ for bituminous [31]. As discussed earlier in Material and Methods, the ANN was used as a basis in analysing C, MM, $\mathrm{O}, \mathrm{H}$, and $\mathrm{N}$, while $\mathrm{S}$ was analyzed by the digital bomb calorimeter.

Firing of coal in power plant station leads to $15-30 \%$ of the nitrogen content in it being converted to $\mathrm{NO}_{\mathrm{x}}$ [32]; therefore, having the percentage mass of nitrogen from Table $2, \mathrm{NO}_{\mathrm{x}}$ can be estimated. Total weight of $\mathrm{SO}_{2}$ is calculated by multiplying 19 with sulphur content in a given sample of coal and total sample of weight burnt [33]. Having the $\mathrm{S}$ in Table 2 , hence, $\mathrm{SO}_{2}$ in any quantity of Mui and Taru coal can be estimated when required.

3.3. Estimation of Calorific Value of Mui and Taru Basin Coal. The gross calorific value (GCV) was obtained by multivariable linear regression equation [23]: 
$\mathrm{GCV}=7115.197-23.971 \times \mathrm{MC}-81.3121 \times A+20.7421 \times \mathrm{FC}$.

This resulted in $6474.78 \mathrm{kCal} / \mathrm{kg}(27090.48 \mathrm{~kJ} / \mathrm{kg})$ for Muil coal, $6021.95 \mathrm{kCal} / \mathrm{kg}(25195.84 \mathrm{~kJ} / \mathrm{kg})$ for Mui2, and $5022.91 \mathrm{kCal} / \mathrm{kg}(21015.86 \mathrm{~kJ} / \mathrm{kg})$ Taru basin coal. These are given in Table 3.

Grading of this coal therefore gives Muil as grade $\mathrm{A}$, Mui2 coal as grade $B$, while Taru basin coal lies in grade $C$ [34].

3.4. Temperature-Weight Analysis. The results from temperature-weight analysis are shown in Figure 7.

From Figure 7, there was insignificant weight loss for the first $50^{\circ} \mathrm{C}$. Between 50 and $100^{\circ} \mathrm{C}$, there were $2.95,4.32$, and $2.59 \%$ loss; this was due to moisture loss and drying before burning starts [21] and a negligible change up to $150^{\circ} \mathrm{C}$. This was then followed by devolatilization; here, carbonaceous substances decompose thermally releasing volatiles which are combustible [35]. Organic compounds are broken down resulting in component gases. There was rapid weight loss of $82.24,79.72$, and $70.27 \%$ up to $650^{\circ} \mathrm{C}$ for Mui1, Mui2, and Taru coal, respectively. Coal burns at high temperature, which is due to high density as a result of closely packed particles [36]. Between $650^{\circ} \mathrm{C}$ and $950^{\circ} \mathrm{C}$, there was very minimal weight loss. At this point, char combustion is over; the percentage left was $9.23,11.48$, and $24.77 \%$ for Mui1, Mui2, and Taru which were approximately equal to the ash content attained from proximate analysis results.

3.5. Temperature Variation in a Fluidized Bed Combustor. During the continuous combustion of the two samples of coal from Mui and Taru basin, the results obtained were recorded and plotted separately as shown in Figure 5.

From Figure 5, the profiles for temperature from the sensors located in different regions showed consistency rise and the plateau after around $150^{\text {th }}$ minute for both Mui and Taru coal. The highest temperature was recorded by sensor $T_{1} 855$ and $854^{\circ} \mathrm{C}, T_{2} 670$ and $661^{\circ} \mathrm{C}, T_{3} 621$ and $631^{\circ} \mathrm{C}$, and $T_{4} 440$ and $475^{\circ} \mathrm{C}$ for Mui and Taru coal, respectively. The temperature change at different bed heights was highest $\left(152^{\circ} \mathrm{C}\right)$ at $T_{1}$ and least at $T_{4}\left(94^{\circ} \mathrm{C}\right) ; T_{2}$ and $T_{3}$ were $135^{\circ} \mathrm{C}$ and $118^{\circ} \mathrm{C}$, respectively, for Mui coal. A similar trend was observed for Taru coal. This showed that temperature increase was highest at the point of combustion. Volatile combustion takes place at freeboard [21], probably why highest temperature was by $T_{1}$ which is slightly above the base holding the burning coal. Note that the electric heaters were switched off once the temperature sensors $T_{1}, T_{2}, T_{3}$, and $T_{4}$ were 703 , 535,503 , and 346 , respectively.

3.6. Examination of Drained Material after Combustion in the FBC. The FBC was left to cool for some time after switching off the heaters, the lower valve opens, and the combusted fuel together with the bed material drained and examined, as shown in Figure 4.
Table 3: GCV for the Mui and Taru basin coal.

\begin{tabular}{lc}
\hline Coal sample & GCV $(\mathrm{kJ} / \mathrm{kg})$ \\
\hline Mui1 & 27090 \\
Mui2 & 25196 \\
Taru & 21016 \\
\hline
\end{tabular}

Keenly observing the drained material from the FBC after the combusted coal and the bed material, the particles were seen held together by materials in molten state. This was similar in both coal samples. This indicated proof of agglomeration is said to take place when the ash from the coal changes to molten state at very high temperature and holding the bed material together [37].

3.7. Flue Gases Analysis. The results obtained from the gas analyzer at different temperature levels are shown in Figure 6. The gas analyzed includes hydrogen sulfide, carbon monoxide, oxygen, and the percentage level of combustibles.

From Figure 6(a), $\mathrm{H}_{2} \mathrm{~S}$ in Taru coal was maximum $(20 \mathrm{ppm})$ at $500^{\circ} \mathrm{C}$, while Mui coal is maximum $(6 \mathrm{ppm})$ at $750^{\circ} \mathrm{C} . \mathrm{H}_{2} \mathrm{~S}$ and polysulfide are obtained from $\mathrm{S}$ through a chemical conversion by bacteria available in ground water; they are toxic, leads to corrosion of equipment, odors, and emissions, which negatively affect the environment and human beings [38, 39].

For $\mathrm{CO}$ as shown in Figure 6(b), a sharp increase was observed between $200^{\circ} \mathrm{C}$ and $450^{\circ} \mathrm{C}$ for Mui coal and gradually increases for Taru basin coal for temperatures between $300^{\circ} \mathrm{C}$ and $600^{\circ} \mathrm{C}$. The highest level of $2000 \mathrm{ppm}$ of CO was recorded from the Mui coal, while $687 \mathrm{ppm}$ of CO was observed for the Taru basin sample. During the combustion of coal, an increase in the concentration of flue gases with temperature is noted. Carbon monoxide forms the highest percentage, since it is formed in very large quantities [40]. The concentration of CO above 150-200 ppm may cause unconsciousness and healthy problems, especially for patients with related diseases. When fossil fuels for example coal are combusted, carbon monoxide and carbon dioxide are emitted. These gases cause the greenhouse house effect [41]. They therefore need to be stored or separated to minimize their concentration in the ozone layer. To achieve this, there is need to combust such fuel (coal) in conditions where oxygen is enhanced.

Percentage level of oxygen recorded in the beginning was $20.3 \%$ as shown in Figure 6(c). This is approximately the level of oxygen in the atmosphere. This then dropped gradually as combustion continued, with Taru coal recording maximum drop up to $15 \%$. Consumption of oxygen during combustion differ with different coal ranks even at same temperature; however, the change is nonlinear; probably, this is why we have different levels of oxygen at same temperature for different coal samples [42]. In Figures 6(a), 6(b), and 6(d), the number of constituent gases in flue gases was rising. During combustion of coal, a number of reactions tend to take place. These include the physical adsorption of oxygen gas, the chemical adsorption of oxygen gas leading to a complex compound $\left(\right.$ coal- $\left.\mathrm{O}_{2}\right)$, 
and lastly the oxidation process, in which combusted hot coal reacts with oxygen giving rise to flue gases such as carbon dioxide, carbon monoxide, and water vapour [25]. There is always an increased portion of carbon that is combusted when the concentration of oxygen is high in a given mixture of gases [41]. Referring to Figure 6(c), highest combustion of the three samples of coal took place between $500^{\circ} \mathrm{C}$ and $650^{\circ} \mathrm{C}$, Taru coal sample recording more $\mathrm{O}_{2}$ consumption. This therefore indicates that the portion of Taru coal that is combusted is more than that of Mui coal within the same range of temperatures. The level of oxygen later rose to almost the atmospheric level, implying that coal had been used up; hence, no more oxygen was being used up.

From Figure 6(d), the percentage level of combustibles was observed to rise for all the coal samples. For Taru coal, increase in the percentage level of combustibles was noted to start at $150^{\circ} \mathrm{C}$, with a small plateau at $200^{\circ} \mathrm{C}$ and another at $350^{\circ} \mathrm{C}$, after which it sharply rose at $400^{\circ} \mathrm{C}$ to attain a maximum percentage level of $58 \%$ at $450^{\circ} \mathrm{C}$ and later dropped drastically to zero at $500^{\circ} \mathrm{C}$.

During the rise in the percentage level of combustibles, there was noted decrease in the percentage level of $\mathrm{O}_{2}$. This means that the $\mathrm{O}_{2}$ was being utilized in combustion of the combustibles in the coal. The percentage level of $\mathrm{O}_{2}$ started falling at $350^{\circ} \mathrm{C}$ and drastically at $450^{\circ} \mathrm{C}$ where the percentage level of combustibles was highest (58\%). Muil and Mui2 samples showed their percentage level of combustibles gradually rise starting at temperature $300^{\circ} \mathrm{C}$ attaining a maximum of $14 \%$ at $750^{\circ} \mathrm{C}$ and $650^{\circ} \mathrm{C}$, respectively. The lowest percentage of $\mathrm{O}_{2}$, which is $18.5 \%$ for Muil and $17.9 \%$ for Mui 2 coals, was attained at $600^{\circ} \mathrm{C}$. Like in the case of Taru coal, this showed that oxygen was being used excessively where the combustibles were more. In comparison, the samples from the two regions, that is Mui and Taru, Taru coal has more combustibles, highest at 58\% compared to Mui coal samples which attain a maximum of $14 \%$ combustibles. Therefore, this means that more oxygen will be required for a complete combustion of Taru coal than required for Mui coal. Data for Figure 6 were continuously taken and recorded as the experiment was being run. This was ideal to detect the change in the flue gases percentages.

\section{Conclusion}

Newly discovered coal in the Mui and Taru, in Kitui and Kilifi counties in Kenya, has opened new fossil fuel resource for Kenya. Characteristic fuel and FBC combustion properties were studied to establish the commercial potential of the coal. Proximate analysis showed that FC and VM (mass \%) varied as Mui1' Mui2' Taru and A (mass\%) varied as Taru'Mui2'Muil. MC for the samples did not follow a trend. Ultimate analysis (mass\%) gave the trend for $\mathrm{C}$ and $\mathrm{H}$ as Mui1'Mui2'Taru and for $\mathrm{MM}$ and $\mathrm{N}$ as Taru 'Mui2' Muil. Exception was Mui2 with highest $\mathrm{O}$ and S. Caloric values followed the expected order: Mui1 'Mui2' Taru. The study of weight loss upon heating showed a close behavior for all samples for up to $350^{\circ} \mathrm{C}$, and thereafter, Taru sample displayed a lower loss due to higher A. All samples displayed a similar temperature profile and agglomeration in FBC. Flue gas analysis showed better combustion behavior for Mui coal and higher oxygen requirement for Taru for a similar combustion. All the samples proved the potential for commercial exploitation; however, Mui coal was found to be better than Taru coal.

\section{Data Availability}

The data used to support the findings of this study are included within the article and are available from the corresponding author upon request.

\section{Conflicts of Interest}

The authors declare that they have no conflicts of interest.

\section{Acknowledgments}

The authors profoundly acknowledge the African Development Bank for the financial support and the Ministry of Energy for helping in obtaining the coal samples for research.

\section{References}

[1] N. Howard, M. Galeotti, A. Lanza, and D. Kankana, Economic Development and Energy Consumption in the GCC: An International Sectional Analysis, Springer, Berlin, Germany, 2017.

[2] H. Lofgren and P. Kumar, The Challenges of Achieving Kenya's Vision 2030: A Macro Perspective, World Bank, Washington, DC, USA, 2007.

[3] P. Kimuyu, J. Mutua, and J. Wainana, Role of Renewable Energy in Promoting Inclusive and Sustainable Development in Kenya, School of Economics, University of Nairobi, Energy Regulation Commission, Nairobi, Kenya, 2012.

[4] http://energypedia.info/wiki/Fosil_Fuel_Resources_in_ Kenya.

[5] https://ctwkenya.com/power-energy 2020.

[6] Ministry of Energy, Kenya Electrical Power Commercial Guide, Ministry of Energy, Nairobi, Kenya, 2017.

[7] Ministry of Energy, Kenya National Energy Efficiency and Conservation Strategy, Ministry of Energy, Nairobi, Kenya, 2020.

[8] M. J. Chadwick, N. H. Highton, and N. Lindman, Environmental Impact of Coal Mining and Utilization: A Complete Revision of Environmental Implication of Expanded Coal Utilization, Elsevier, Amsterdam, Netherlands, 1987.

[9] C. W. Montgomery, Environmental Geology, McGraw-Hill Higher Education, New York, NY, USA, 6th edition, 2003.

[10] K. G. Tushar and A. P. Mark, "Energy resources and systems," Renewable Resources, Springer, Berlin, Germany, 2011.

[11] A. Mishra, "Assessment of coal quality of some Indian coals," B.Tech. thesis, Department of Mining Engineering National Institute of Technology, Rourkela, India, 2009.

[12] International Energy Agency Outlook, Energy Information Administration Office of Integrated Analysis and Forecasting, US Department of Energy, Washington, DC, USA, 2008.

[13] Ministry of Energy and Petroleum (MOEP), Draft National Energy and Petroleum Policy, Ministry of Energy and Petroleum (MOEP), Nairobi, Kenya, 2015.

[14] https://www.worldometers.info/coal/Kenya-coal 2020. 
[15] M. Mutemi and D. Samoei, "Status of water quality in the coal rich Mui basin on Kitui county, Kenya," Pure and Applied Science, vol. 1, no. 2, 2012.

[16] https://www.the-star.co.ke/counties/eastern/2020-09-02kenya-undecided-on-mining-coal-in-kituis-mui-basin 2020.

[17] http://www.nexus.or.ke/index.php/news/item, 2018.

[18] P. Basu and S. A. Fraser, Circulating Fluidized Bed Boiler: Design and Operation, Stonehem: Butterworth- Hineman, Oxford, UK, 1991.

[19] M. Radopvanoic, Fluidized Bed Combustion, Hemisphere Publishing Corporation, London, UK, 1986.

[20] J. Krishnaiah, A. Lawrence, and R. Dhanuskodi, "Artificial neural networks model for predicting ultimate analysis using proximate analysis of coal," International Journal of Computer Applications, vol. 44, no. 2, pp. 9-13, 2012.

[21] H. K. Tarus, "Combustion characteristics of cow dung using a fluidized combustor," M.Sc. thesis, Moi University, Eldoret, Kenya, 2013.

[22] A. K. Mukherjee, M. M. Alam, and S. Ghose, "Micro hardness characteristics of Indian coal and lignite," Fuel, vol. 68, no. 5, pp. 670-673, 1989.

[23] S. Kailash, "Prediction of calorific value of Indian coal by artificial neural network," B.Tech. thesis, Department of Mining Engineering, National Institute of Technology, Rourkela, India, 2015.

[24] V. Fierro, J. L. Miranda, C. Romero et al., "Prevention of spontaneous combustion in coal stockpiles: experimental results in coal storage yard," Fuel Processing Technology, vol. 59, no. 1, pp. 23-34, 1999.

[25] J. N. Carras and B. C. Young, "Self-heating of coal and related materials: models, application and test methods," Progress in Energy and Combustion Sciences, vol. 20, no. 1, pp. 1-15, 1994.

[26] E. Pankaj, Coal Properties and Its Influence on Boilers, NTPC Ltd, New Delhi, India, 2017.

[27] L. J. Bureska, "Influence of coal quality to the boiler efficiency and opportunity for its improvement," Termotehnika, vol. 43, no. 1-4, pp. 59-65, 2017.

[28] B. D. Hong and E. R. Slatick, Carbon Dioxide Emission Factors for Coal, US Energy Information Administration, Washington, DC, USA, 1994.

[29] S. M. Stanford and M. N. Evans, "Characteristics of thermal coal used by power plant in Waterberg region of South Africa," Chemical Engineering Transactions, vol. 57, pp. 511516, 2017.

[30] S. J. Shankar, "Investigation into spontaneous combustion characteristics of some Indian coals and correlation study with their intrinsic properties," B.Tech. thesis, Department of Mining Engineering, National Institute of Technology, Rourkela, India, 2011.

[31] G. L. Tingey and J. A. Morrey, Coal Structure and Reactivity, A Battelle Energy Program Report: Battelle Pacific Northwest Laboratories Richland Washington, Springer, Berlin, Germany, 1973.

[32] L. Wyoming, $\mathrm{NO}_{x}$ Emission Produced with Combustion of Powder River Basin Coal in a Utility Boiler, Western Research Institute, Larame, WY, USA, 1997.

[33] C. K. Varshney and J. K. Garg, "A quantitative assessment of sulfur dioxide emission from fossil fuels in India," Journal of the Air Pollution Control Association, vol. 28, no. 11, p. 1141, 1978.

[34] S. K. Kawatra, S. K. Timothy, and C. Eisele, "Coal desulfurization: high efficiency and preparation methods," Technology Engineering, Taylor and Francis, Milton, UK, 2001.
[35] F. U. Datin, U. Hiromoto, and D. Bukin, "Change of combustion characteristic of Indonesian low rank coal due to upgraded coal process," Fuel Processing Technology, vol. 87, no. 11, pp. 1007-1011, 2006.

[36] H. A. Rasugu, "Combustion properties on fuel properties of finger millet briquettes," M.Sc. thesis, Moi University, Elboret, Kenya, 2014.

[37] H. J. M. Visser, Ash/Bed Agglomeration in Fluidized in Fluidized-Bed Combustion and Gasification, Energy Research Centre of the Netherlands, Sint Maartensvlotbrug, Netherlands, 2001.

[38] Occupational Safety and Health Administration (OSHA), OSHA QuickTake, Occupational Safety and Health Administration, vol. 14, no.7, Washington, DC, USA, 2015.

[39] WHO Region for Europe Copenhagen, Denmark, "Effect of sulphur dioxide on vegetation: critical levels," Air Quality Guidelines, WHO, Geneva, Switzerland, 2nd edition, 2000.

[40] W. R. Karolina and A. Smolinski, "Study of the hazard of endogenous fires in coal mines-a chemometric approach," Energies, vol. 11, no. 11, p. 3047, 2018.

[41] T. Klajny, J. Krzywanski, and W. Nowak, "Mechanism and kinetics of coal combustion in oxygen enhanced condition," in Proceedings of the Conference: 6th International Symposium on Coal Combustion, Wuhan, China, December 2007.

[42] X. Qi, D. Wang, X. Zhong, J. Gu, and T. Xu, "Characteristics of oxygen consumption of coal at programmed temperatures," Mining Science and Technology (China), vol. 20, 2010. 